
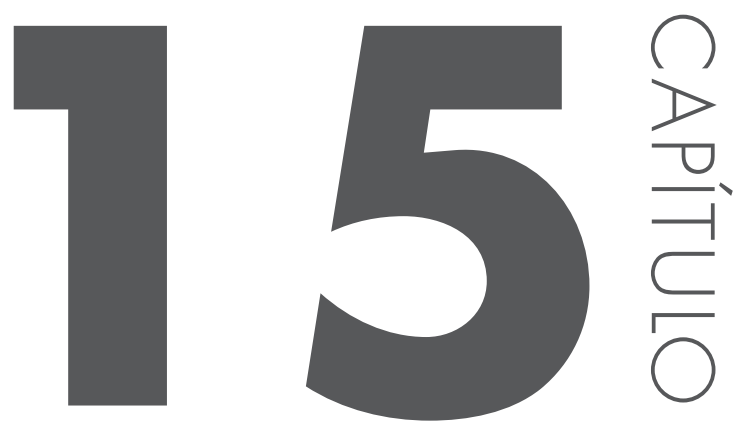

\title{
BASES DO SISTEMA IMUNOLÓGICO ASSOCIADO À MUCOSA INTESTINAL
}

Juliana Lauar Gonçalves

Juliana Navarro Ueda Yaochite

Camila de A. Almeida de Queiroz

Carlos Campos Câmara

Reinaldo B. Oriá

O intestino é considerado importante local de interação antigênica, uma vez que está em constante contato com microrganismos comensais, patogênicos, bem como moléculas derivadas de alimentos ingeridos. Assim, o desenvolvimento e progressão das respostas imunológicas nesse local devem ser regulados, evitando por um lado uma reação exacerbada e prejudicial ao organismo frente a antíge- 
nos que devem ser incorporados, e ao mesmo tempo promovendo uma resposta efetiva contra patógenos, quando necessária.

Células do sistema imunológico, como macrófagos, células dendríticas, linfócitos $\mathrm{T}$ e linfócitos $\mathrm{B}$ (plasmócitos) produtores de anticorpos da classe IgA, encontradas em associação à mucosa intestinal, juntamente com fatores como a microbiota comensal, o peristaltismo, a produção de muco e substâncias antimicrobianas produzidas por células intestinais, atuam em conjunto para proporcionar o equilíbrio do organismo em relação aos agentes fisiológicos ou patogênicos nesse microambiente. Além disso, as células T reguladoras e produção de citocinas anti-inflamatórias na mucosa gastrointestinal proporcionam, na maioria das vezes, um ambiente de tolerância contra antígenos provenientes da dieta e da microbiota residente, evitando assim o desenvolvimento de uma resposta inflamatória indesejável contra essas moléculas.

\subsection{BARREIRA EPITELIAL INTESTINAL}

A camada epitelial intestinal tem função bimodal de maximizar a absorção de nutrientes digeridos, enquanto impede a passagem dos componentes luminais, tais como bactérias e componentes intactos de alimentos. Mais de $80 \%$ das células epiteliais intestinais são colunares e estão envolvidas na absorção de nutrientes e funções metabólicas. O epitélio intestinal é composto primariamente por enterócitos conectados por junções firmes (zônulas de oclusão), formando uma barreira com permeabilidade seletiva entre a bainha epitelial e o conteúdo luminal. Essas células são responsáveis por absorver nutrientes do lúmen e liberar IgA secretória para o lúmen, como também participam ativamente da imunidade por produzirem peptídeos antimicrobianos e citocinas próinflamatórias em resposta à ativação de seus receptores de reconhecimento de patógenos. A camada epitelial de revestimento possui células especializadas representadas por três linhagens que têm origem da mesma célula-tronco: enterócitos absortivos, células caliciformes produtoras de muco e células enteroendócrinas produtoras de hormônios.

As células de Paneth (encontradas na base das glândulas ou criptas do intestino delgado) e as células caliciformes (distribuídas no epitélio de revestimento e nas glândulas intestinais) contribuem para a imunidade inata com o suporte na função da barreira epitelial. As células de Paneth residem nas criptas do intestino delgado (Figura 15.1) e secretam grandes quantidades de peptídeos antimicrobianos. Essas células também produzem uma matriz de agentes antimicrobianos (tais como as defensinas e lisozimas) que impede o contato de microrganismos com as células-tronco intestinais na base das criptas e regula a microbiota no lúmen intestinal, enquanto células caliciformes produzem mucinas que formam uma camada protetora do epitélio e evitam o contato epitelial direto com microrganismos do 
lúmen. Recentemente foi descoberto que as células de Paneth contribuem para formar um nicho para células-tronco intestinais, as células colunares da base $\mathrm{da}$ cripta $(\mathrm{CBC})$, identificadas pelo marcador Lgr5 (leucine-rich repeat containing G-protein coupled receptor 5).

Coletivamente, a barreira epitelial intestinal, somada a outros mecanismos da imunidade inata (incluindo a uma camada de muco saturado com peptídeos antimicrobianos), controla a carga bacteriana na interface entre o lúmen e o epitélio.

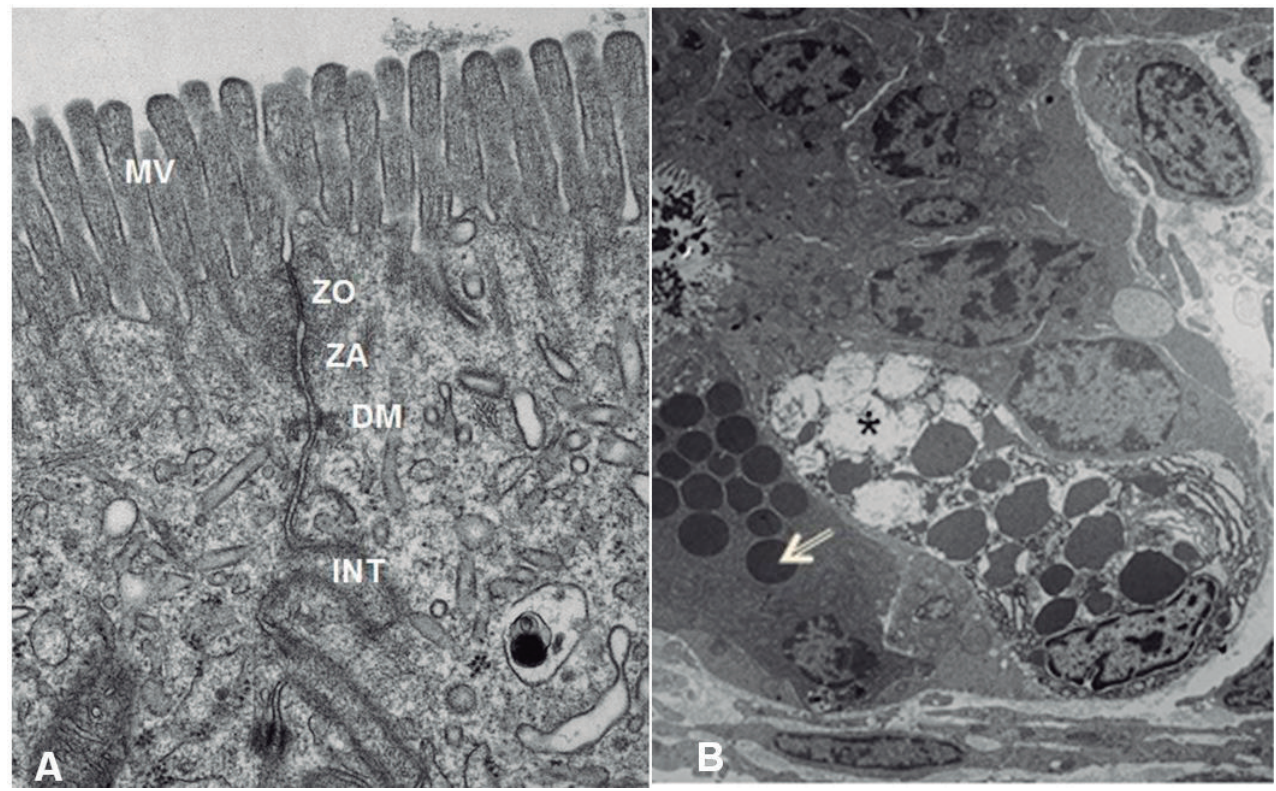

Figura 15.1 - A. Barreira epitelial intestinal. A zônula de oclusão (Z0) representa uma barreira paracelular selativa, regulando o microambiente intestinal. $Z A=$ zônula de adesão; $D M=$ desmosoma; $M V=$ microvilosidade; INT: interdigitações. Microscopia eletrônica. 20.000X. B. Células de Paneth na base da glândula intestinal. Essas células possuem grânulos citoplasmáticos contendo peptídeos antimicrobianos (seta). Notar célula de Paneth, mostrando degranulação (asterisco). Microscopia eletrônica. Aumento: 2.500X. As células de Paneth estão localizadas na base das criptas de Lieberkuhn e produzem proteínas antimicrobianas (duas $\alpha$-defensinas, HD5 e 6, e ainda secretam lisozima, fosfolipase A2 e ReglllA, regenerating islet-derived protein IIIA), e também expressam PRRs, especificamente NOD2, TLR2, TLR4, TLR5 e TLR9. 


\subsection{SISTEMA IMUNOLÓGICO ASSOCIADO À MUCOSA INTESTINAL}

Tecidos linfoides organizados, não encapsulados, constituídos por células do sistema imunológico, são encontrados associados às superfícies mucosas dos tratos respiratório, gastrointestinal e urogenital, e são chamados coletivamente de M.A.L.T (mucosa-asssociated lymphoid tissue/tecido linfoide associado à mucosa). Além do M.A.L.T. (mucosa associated lymphoid tissuel tecido linfoide associado às mucosas), pode-se encontrar na lâmina própria das superfícies mucosas um tecido linfoide difuso, constituído por células imunes amplamente distribuídas.

Especificamente na mucosa do trato intestinal encontra-se o sistema G.A.L.T (gut-associated lymphoid tissue/tecido linfoide associado ao intestino), constituído de tecido linfoide denso, representado por folículos linfoides isolados no intestino grosso ou formando agregados como nas placas de Peyer no íleo (Figura 15.2). As placas de Peyer são estruturas semelhantes a linfonodos, não encapsuladas, formadas por agregados de folículos linfoides com centros germinativos, nas quais os linfócitos T e B estão segregados anatomicamente. Nas placas de Peyer, há indução das respostas imunes adaptativas (apresentação/reconhecimento de antígenos, ativação e diferenciação dos linfócitos) contra antígenos imunogênicos no intestino delgado.

Os antígenos do lúmen intestinal são direcionados para o G.A.L.T a partir do epitélio e não através do sistema linfático ou sanguíneo, como ocorre nos outros órgãos linfoides secundários. Um tipo celular muito importante no transporte dos antígenos no lúmen para as placas de Peyer e folículos linfoides isolados compreende as células M (microfold cells). Essas são células epiteliais achatadas, localizadas em regiões do epitélio da cúpula (também chamado de epitélio associado ao folículo) que recobre a parte superior das placas de Peyer e folículos isolados, capazes de realizar transporte transcelular de proteínas solúveis, partículas inertes e vários microrganismos (vírus, fungos, bactérias) na interface luminal, permitindo que células dendríticas e macrófagos teciduais capturem esses antígenos para serem transportados até os folículos linfoides.

Abaixo do epitélio de revestimento, existe a lâmina própria, um tipo de tecido conjuntivo frouxo, correspondendo ao estroma acima da muscular da mucosa (muscularis mucosae), excluindo assim a submucosa. Nela são encontrados de forma dispersa células dendríticas, macrófagos e mastócitos, que são em grande parte responsáveis pela resposta imune inata na mucosa. As extensões citoplasmáticas de algumas células dendríticas são interdigitadas entre as células epiteliais, possibilitando a captura, processamento e apresentação de antígenos diretamente a partir do lúmen aos linfócitos intraepiteliais e para as células $\mathrm{T}$ de folículos 
linfoides subjacentes. Há também linfócitos T e B efetores (linfócitos T CD4 auxiliares, linfócitos T CD8 citotóxicos e plasmócitos secretores de IgA) previamente ativados/diferenciados nos G.A.L.T ou linfonodos drenantes.

Os linfonodos mesentéricos recebem diversos antígenos provenientes do intestino grosso e delgado, transportados pela linfa. Nos linfonodos mesentéricos, ocorre a diferenciação de linfócitos virgens em células efetoras (linfócitos T auxiliares e citotóxicos, células T reguladoras, plasmócitos secretores de $\operatorname{IgA}$ ), que por fim migram para a lâmina própria intestinal para atuarem diretamente contra $\mathrm{o}$ antígeno cognato.

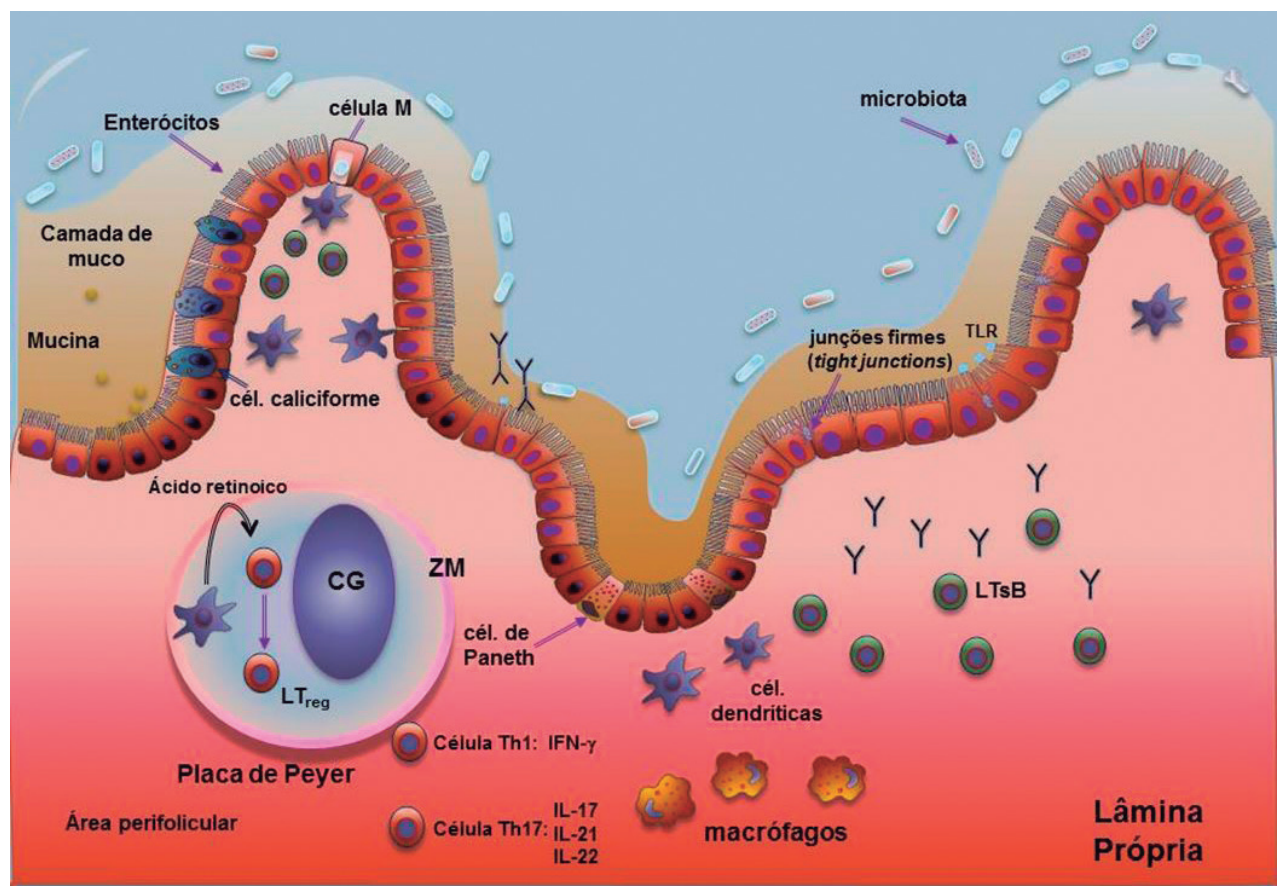

Figura 15.2 - Esquema da região do íleo, mostrando um arranjo nodular da placa de Peyer. 0 epitélio intestinal, contendo enterócitos, que expressam receptores toll-like, e células caliciformes, forma uma barreira paracelular (com junçōes de oclusão ou firmes tight junctions) contra a translocação bacteriana da microbiota. A barreira de muco e de peptídeos antimicrobianos restringe a penetração de bactérias patogênicas. Notar linfócitos B (LTsB) e linfócitos $T$, incluindo células da resposta Th1 e células Th2 e suas citocinas na lâmina própria. Células $M$ (microfold) são importantes para transferir antígenos (sem processá-los) para linfócitos da lâmina própria e linfócitos intraepiteliais (não representadas). Macrófagos e células dentríticas,apresentadoras de antígenos, também estão na lâmina própria. Linfócitos $T$ reguladores ( $\left.\mathrm{LT}_{\mathrm{reg}}\right)$ estão nas placas de Peyer e são formados pela influência do ácino retinoico e TGF- $\beta$. CG=centro germinativo do folículo linfoide; $Z M=$ zona marginal do folículo linfoide. 


\subsection{RESPOSTA IMUNE INATA NA MUCOSA DO SISTEMA INTESTINAL}

A ação coordenada das células e moléculas da imunidade inata representa a primeira barreira seletiva do organismo, atuando de forma imediata e não específica contra um determinado agente potencialmente invasor que pode ser prejudicial, além de possibilitar o desenvolvimento de mecanismos da resposta imune adaptativa, quando necessários. A camada epitelial intestinal constitui a primeira barreira física de proteção contra invasão tecidual de agentes patogênicos no lúmen do intestino. O epitélio intestinal tem uma taxa de renovação rápida a cada 3-4 dias. Em situações na qual há dano nas células epiteliais, essas devem ser rapidamente substituídas para que a barreira epitelial seja mantida sem causar prejuízos ao indivíduo. Além da função de barreira, as células epiteliais intestinais (células de Paneth) produzem moléculas antimicrobianas (defensinas) que causam alterações na parede celular das bactérias, promovendo sua lise celular.

As mucinas, secretadas por células caliciformes em quantidades copiosas (três litros/dia), criam um gel viscoso protetor que dificulta a penetração microbiana. $\mathrm{O}$ muco também atua como um lubrificante para reduzir a abrasividade física da mucosa e participa da proteção da mucosa de danos induzidos por ácidos e outras toxinas luminais. O transporte ativo de cloro por células epiteliais promove fluxo de fluido intraluminal que lava os agentes nocivos. Secreções mucoides são ricas em anticorpos IgA que efetivamente se ligam e agregam bactérias, prevenindo aderência à mucosa e colonização (assim chamada exclusão imune) e também concentram peptídeos antimicrobianos produzidos pelas células de $\mathrm{Pa}$ neth. A redução da secreção de bile no intestino facilita a translocação bacteriana, e a exposição à bile durante o crescimento bacteriano diminui a internalização epitelial de bactérias entéricas.

A barreira mais crítica contra a invasão de microrganismos e produtos microbianos intraluminais, entretanto, é o próprio epitélio. Estruturalmente, o intestino compreende um epitélio de camada única colunar organizado em vilosidades. Complexos de junção célula-célula especializados permitem uma permeabilidade paracelular seletiva (junções de oclusão), mantêm adesão intracelular (junções intermediárias e desmossomos) e permitem a comunicação intercelular (junções lacunares, gap junctions). A zônula de oclusão é uma banda circunferencial de junções firmes que limitam a passagem paracelular de íons e fluidos. Normalmente, junções firmes excluem o movimento passivo de componentes hidrofílicos prevenindo, por exemplo, movimento transepitelial de bactérias e também macromoléculas como lipopolissacarídeos (LPS), peptidoglicanos-polissacarídeos etc.

Além disso, sabe-se que bactérias mortas também translocam como um processo biológico normal. Após serem sensibilizadas, células apresentadoras de an- 
tígeno e células imunes imaturas do G.A.L.T. deixam o trato intestinal, migram através do ducto torácico, participam na imunidade sistêmica e preferencialmente colonizam a mucosa intestinal como células maduras T e B. Assim, é concebível considerar a translocação bacteriana como um processo provavelmente fisiológico e essencial, regulando a imunidade sistêmica e a tolerância a inúmeros antígenos que entram em contato com o epitélio intestinal. Além disso, células dendríticas podem fazer uma "amostragem" de bactérias comensais (que expressam a receptor-1-de quimocina CX3C, CX3CR1) a partir de seus processo entre as células epiteliais de revestimento do intestino e transportam essas bactérias para os linfonodos mesentéricos, induzindo a produção de IgA secretória e regulando a resposta imunológica intestinal.

O início da resposta imune inata celular é mediado pelo reconhecimento de padrões moleculares associados a patógenos (PAMPs) pelos receptores celulares de reconhecimento de padrões (PRRs). Os PRRs mais estudados são os receptores do tipo Toll (TLRs/Toll-like receptors) que estão localizados tanto na membrana plasmática da célula como em associação à membrana de endossomas, e podem ser expressos por células epiteliais intestinais (enterócitos), macrófagos, células dendríticas, linfócitos B e T e células do estroma. O reconhecimento do PAMP

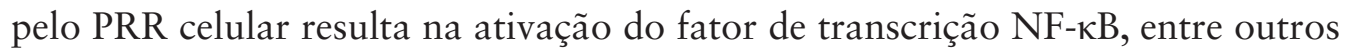
fatores de transcrição, culminando na produção de citocinas e quimiocinas que promovem recrutamento de várias células inflamatórias, bem como no aumento da expressão de moléculas coestimulatórias por células apresentadoras de antígenos. Além disso, a sinalização de TLRs no intestino influencia a proliferação de células epiteliais, a produção de IgA secretória por células B, a manutenção das "tight junctions" e expressão de peptídeos antimicrobianos por células epiteliais. Além dos TLRs, outros PRRs estão envolvidos no reconhecimento de PAMPs de microrganismos no intestino e desenvolvimento da resposta inflamatória, como receptores citoplasmáticos do tipo NOD (NOD like receptors/NLRs) que reconhecem produtos derivados de bactérias e receptores do tipo RIG (RIG like receptors/RLRs) que atuam como sensores de material genético viral no citoplasma.

A ruptura da integridade da barreira epitelial, caracterizada pelo aumento da permeabilidade intestinal, resulta na invasão tecidual por bactérias comensais, como também no aumento dos antígenos dietéticos intactos na mucosa intestinal que levam à produção excessiva de citocinas inflamatórias pelas células do sistema imune na mucosa, podendo originar uma resposta imune exacerbada e patológica, culminando em um processo de inflamação intestinal. 


\subsection{POPULAC̣ÕES DE LINFÓCITOS T NA MUCOSA INTESTINAL}

Algumas populações de linfócitos T estão especificamente localizadas acima da lâmina própria e da membrana basal do epitélio intestinal, situadas entre as células epiteliais de revestimento e exibem características diferentes de outros linfócitos T encontrados na periferia. Em virtude de sua localização histológica, esses linfócitos são denominados de linfócitos T intraepiteliais (Figura 15.3) e por estarem em contato direto com os enterócitos e com os antígenos no lúmen intestinal participam da resposta imune efetora contra microrganismos patogênicos e também dos processos imunorreguladores na mucosa intestinal. Esses linfócitos são heterogêneos, majoritariamente $(80 \%)$ de fenótipo CD8, com abundantes grânulos citoplasmáticos contendo moléculas citotóxicas, capacidade de produzir diversas citocinas (como IFN- $\gamma$, IL-2, IL-4 ou IL-17) e podem se dividir em populações celulares que expressam na superfície o receptor de antígenos (TCR/T cell receptor) constituído de cadeias do tipo $\alpha \beta$ ou $\gamma \delta$.

Os linfócitos T intraepiteliais "naturais" $\left(\mathrm{CD} 8 \alpha \alpha^{+}\right.$ou CD8 $\alpha \alpha^{-}$com expressão de TCR $\gamma \delta$ ou TCR $\alpha \beta$ ) adquirem seu fenótipo ativado durante o desenvolvimento no timo, com antígenos próprios, enquanto os linfócitos T intraepitelias "induzidos" $\left(\mathrm{CD} 4^{+}\right.$ou $\left.\mathrm{CD} 8 \alpha \beta^{+} \mathrm{TCR} \alpha \beta^{+}\right)$são a progênie de células T convencionais que foram ativadas após maturação tímica, em resposta a um antigeno periférico.

A população dominante entre os linfócitos T intraepiteliais é a CD $8 \alpha \beta^{+} /$ TCR $\alpha \beta^{+}$, que entra no epitélio intestinal por meio da expressão aumentada de integrinas específicas e receptores de quimiocinas após sua ativação em órgãos linfoides secundários.

Os linfócitos T intraepiteliais naturais $\mathrm{TCR} \gamma \delta^{+}$possuem funções cruciais na mucosa intestinal, incluindo a manutenção da função da barreira epitelial (promoção do reparo da barreira, controle do crescimento das células epiteliais, secreção de TGF- $\beta$ ), homeostase do tecido e proteção contra patógenos intestinais (produção de citocinas inflamatórias, citotoxicidade). 


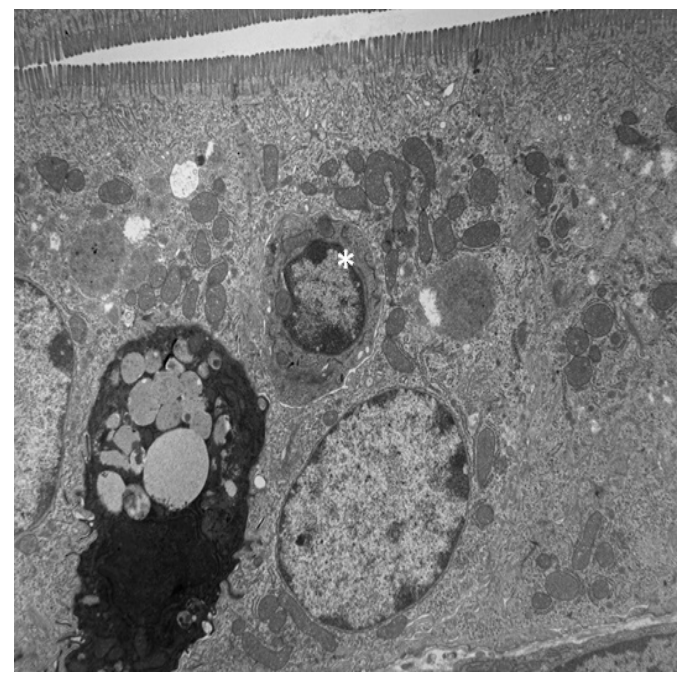

Figura 15.3 - Ultrafotografia do epitélio intestinal com um linfócito intraepitelial (asterisco). Os linfócitos intraepiteliais têm um papel importante na homeostase, mas podem participar de respostas inflamatórias e contribuir para reparo em caso de lesão da barreira epitelial. A maioria dos linfócitos intraepiteliais representa células T CD8+. Aumento 3.000X.

A mucosa intestinal contém ainda outras populações de linfócitos T, localizados no interior dos G.A.L.T (placas de Peyer e folículos linfoides isolados), ou de forma difusa ao longo da lâmina própria do intestino. Cerca de $80 \%$ de todos os linfócitos no nosso corpo estão localizados na mucosa do trato gastrointestinal. Os linfócitos T são essencialmente $\mathrm{CD}^{+}{ }^{+}$ou $\mathrm{CD}^{+}\left(\right.$ambos TCR $\left.\alpha \beta^{+}\right)$, exibem um fenótipo de memória (CD45RD) e se associam à mucosa intestinal por meio da expressão de integrinas específicas $(\alpha 4 \beta 7)$ e receptores de quimiocinas (CCR9) que direcionam esses linfócitos após sua ativação e diferenciação em células efetoras.

Para que a resposta imune adaptativa contra antígenos entéricos seja montada, é necessário que os linfócitos $\mathrm{T}$ virgens (naive) intravasculares se dirijam ao G.A.L.T e aos linfonodos mesentéricos drenantes, onde irão ser ativados, com expansão clonal, polarização/diferenciação em células efetoras do tipo Th1 e/ou Th17 após interação inicial com a célula apresentadora de antígenos. Em seguida, os linfócitos $\mathrm{T}$ efetores saem do tecido linfoide via vasos linfáticos eferentes, entram na circulação sanguínea sistêmica e retornam novamente para o intestino onde vão auxiliar no controle/eliminação de determinado antígeno. A circulação dos linfócitos a partir da circulação periférica (sangue periférico) para outros tecidos, incluindo a mucosa do intestino, é um aspecto importante na vigilância da imunidade, sendo esse processo conhecido como recirculação linfocitária.

A entrada dos linfócitos $\mathrm{T}$ no tecido linfoide e extralinfoide é regulada por receptores de adesão celular (selectinas, integrinas) entre os linfócitos $\mathrm{T}$ e seus 
respectivos ligantes no endotélio vascular. As células endoteliais representam uma barreira física entre o sangue e o tecido da mucosa, mas que pode ser atravessada por leucócitos no sangue. A fim de assegurar um rápido movimento de leucócitos através do endotélio, os leucócitos interagem com receptores/ligantes expressos nas células endoteliais após sua ativação por citocinas/moléculas próinflamatórias produzidas por células teciduais residentes e células inflamatórias previamente ativadas na mucosa intestinal. Esse processo de migração dos leucócitos para a mucosa intestinal é facilitado pela interação de selectinas, integrinas, bem como receptores de quimiocinas expressos nos leucócitos com seus ligantes expressos no endotélio vascular.

Muitos receptores estão implicados na migração dos linfócitos T efetores para a mucosa intestinal, como a integrina $\alpha 4 \beta 7$, cujo ligante é o MAdCAM-1 (molécula de adesão celular 1), constitutivamente expressa na lâmina própria do endotélio; a integrina $\alpha \mathrm{E}$ (CD103) $\beta 7$, cujo ligante é a E-caderina expressa na superfície basolateral dos enterócitos e o receptor de quimiocina CCR9 que tem como ligante a CCL25 (também conhecida como TECK) produzida por pequenas células epiteliais intestinais.

Uma vez que os linfócitos $\mathrm{T}$ efetores retornam ao intestino (processo denominado de homing), eles são novamente expostos aos antígenos que desencadearam a resposta imune, que por sua vez, já está amplificada e conta com uma população mais diversa de células apresentadoras de antígenos como macrófagos, linfócitos B, além das células dendríticas. Nesse novo contato com o antígeno (promovido por células apresentadoras de antígenos), os linfócitos T efetores respondem de modo mais rápido e vigoroso, secretando citocinas como IFN- $\gamma$, IL17, TNF- $\alpha$, linfotoxina- $\alpha$ ou IL-2, dependendo do perfil da célula T efetora (Th1 ou Th17). Cada citocina tem uma função específica na coordenação da resposta imune desencadeada. O IFN- $\gamma$ estimula as células apresentadoras de antígenos a produzirem IL-12 e especificamente em macrófagos ativa a produção de outras citocinas inflamatórias como IL-1, IL-6, IL-8 IL-18 e TNF- $\alpha$, como também espécies reativas de oxigênio e nitrogênio. O IFN- $\gamma$, em combinação com IL-17 e TNF- $\alpha$, ativa as moléculas de adesão nas células endoteliais, aumentando, assim, o recrutamento de leucócitos para aquela determinada região. A citocina IL-2 promove a expansão dos clones de células T efetoras antígeno-específicas e aumenta também a capacidade funcional dos linfócitos T e B.

Entre as células que fazem parte dos mecanismos reguladores na mucosa intestinal, podemos destacar as células $\mathrm{T}$ com fenótipo $\mathrm{CD} 4{ }^{+} \mathrm{CD} 25^{+} \mathrm{Foxp}^{+}{ }^{+}$(células $\mathrm{T}$ reguladoras). Essas células contribuem para a homeostase intestinal e sua deficiência (número/função) está associada ao desenvolvimento de doenças inflamatórias crônicas. Células T reguladoras constituem uma fonte importante da citocina anti-inflamatória IL-10 e estão envolvidas na regulação da resposta imune 
de forma geral, na supressão de células T autorreativas e na manutenção da tolerância imunológica periférica. A maioria das células T reguladoras Foxp $3^{+}$nos tecidos periféricos se diferencia no timo, no entanto, outras populações de células $\mathrm{T}$ reguladoras podem ser diferenciadas nos tecidos periféricos, tais como a mucosa intestinal, a partir de células $T$ virgens estimuladas por alguns fatores como a citocina TGF- $\beta$. As células dendríticas intestinais parecem ser cruciais para a diferenciação de células $T$ reguladoras na mucosa intestinal, por meio da produção local de ácido retinoico que induz a expressão do fator de transcrição Foxp3. As células dendríticas são células apresentadoras de antígenos especializadas que regulam tanto a imunidade adaptativa quanto a imunidade inata. Em estado de homeostasia, elas são encontradas em um estado imaturo (baixa expressão de moléculas de MHC, moléculas coestimuladoras) em toda a lâmina própria e nas placas de Peyer, e podem ser ativadas após contato com produtos microbianos (PAMPS). Após o amadurecimento das células dendríticas, elas se tornam capazes de apresentar antígenos processados aos linfócitos T virgens e direcionar sua diferenciação para os perfis Th1, Th17 ou T reguladora, dependendo da citocina/molécula secretada. As células $T$ reguladoras na mucosa intestinal atuam no desenvolvimento e manutenção da tolerância oral, impedindo que o sistema imunológico seja ativado por antígenos proteicos ingeridos ou administrados pela via oral.

\subsection{LINFÓCITOS B E O PAPEL PROTETOR DA IgA NA MUCOSA INTESTINAL}

Os linfócitos B possuem papel central na resposta imune de mucosas por meio da produção de anticorpos (Figura 15.4). Essas células são ativadas nos linfonodos mesentéricos, nos folículos linfoides isolados da mucosa intestinal e também nas placas de Peyer, havendo citocina TGF- $\beta$ e se diferenciam em células produtoras de anticorpos do isotipo IgA na sua forma dimérica (IgA secretória/S-IgA) ou multimérica. Os plasmócitos migram para a lâmina própria intestinal e secretam os anticorpos que são transportados através do epitélio intestinal para a face luminal por meio do receptor polimérico de IgA (poli-IgR). A IgA tem muitas funções importantes, atuando na proteção do epitélio da mucosa contra patógenos invasores, na modulação da composição da microbiota intestinal e na manutenção da homeostase contra antígenos comensais e antígenos alimentares. A imunolgobulina IgM também é produzida nas mucosas e transportada através do epitélio em concentrações menores do que a IgA dimérica.

As S-IgAs se ligam à bactérias comensais no lúmen intestinal e permitem o transporte delas para a mucosa por meio da ligação do complexo S-IgA/antígeno a receptores específicos expressos nas células $M$ intestinais. Em seguida, células dendríticas de fenótipo tolerogênico na mucosa são estimuladas a produzir IL-10 
e induzir a produção de IgA por linfócitos B nas placas de Peyer. Esse processo de amostragem de microrganismos comensais às células do sistema imune em um microambiente regulador (anti-inflamatório) permite a manutenção da tolerância à microbiota intestinal.

Outra função da S-IgA é atuar no controle de patógenos invasores nas mucosas do hospedeiro. O intestino alberga uma população de células $\mathrm{B}$ que pode seguir uma via de diferenciação em células especializadas (plasmócitos) produtoras de anticorpos S-IgA. Células epiteliais intestinais expressam na superfície basolateral o receptor poli-IgR que permite o transporte transepitelial da S-IgA para a face luminal do intestino. Um fragmento do poli-IgR (componente secretor) fica conjugado à IgA após transporte transepitelial e dificulta a proteólise da molécula no ambiente intestinal rico em preteinase. Uma vez no lúmen, as S-IgAs bloqueiam a aderência de toxinas e microrganismos invasores à superfície epitelial (neutralização), impedindo os efeitos patogênicos causados por eles. Cerca de $1 / 3$ dos indivíduos que apresentam deficiência na produção seletiva de IgA (imunodeficiência primária humana mais comum) são acometidos por infecções recorrentes nos tratos respiratório e gastrointestinal causadas por bactérias, protozoários, entre outros patógenos. Além disso, esses podem manisfestar doenças inflamatórias intestinais crônicas e doenças autoimunes, evidenciando dessa forma o papel crítico da IgA na manutenção da homeostasia e proteção intestinal.

A IgA está no colostro e no leite materno maduro, conferindo proteção ao recém-nascido por meio da transferência de IgA materna. A concentração de IgA no colostro é elevada nos primeiros dias após o parto e em seguida decai rapidamente. A amamentação se faz importante em virtude dessa transferência de anticorpos maternos, conferindo proteção ao recém-nascido até o momento que ele possa sintetizar os próprios anticorpos protetores. 


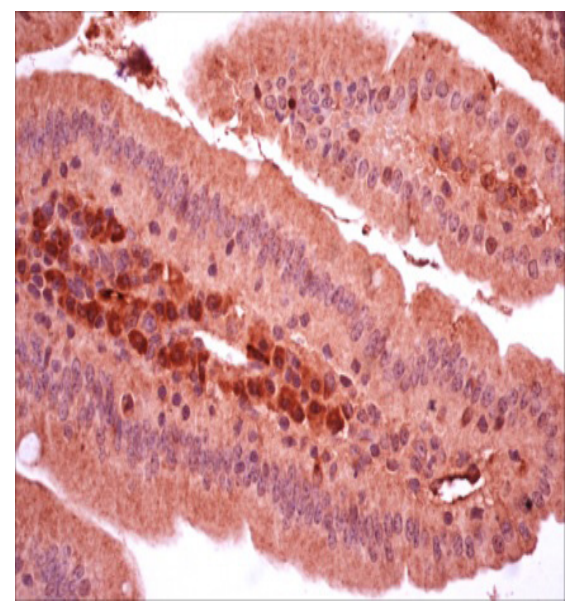

Figura 15.4 - Imuno-histoquímica para CD40, um marcador de linfócitos B, no duodeno de camundongos C57BL/6J. Notar a presença de muitos linfócitos B na lâmina própria da vilosidade intestinal. Os linfócitos B ativados se diferenciam em plasmócitos secretores da imunoglobulina A (IgA). Nesse processo, linfócitos Th ativam linfócitos B, no reconhecimento do complexo peptídeo/MHC-Ill e o engajamento das proteínas $\mathrm{CD} 40 \mathrm{~L} / \mathrm{CD} 40$, com posterior liberacãa de citocinas indutoras de lgA.

Um resumo dos componentes do sistema imunológico associado à mucosa intestinal pode ser visto no Quadro 15.1.

Quadro 15.1: BASES DO SISTEMA IMUNE ASSOCIADO À MUCOSA INTESTINAL

\begin{tabular}{|l|l|}
\hline Barreira epitelial & $\begin{array}{l}\text { Barreira física, camada de células epiteliais (enterócitos e } \\
\text { colonócitos), células caliciformes produtoras de muco, células } \\
\text { de Paneth produtoras de substâncias microbicidas (defensinas), } \\
\text { células transportadoras (células M), linfócitos T intraepiteliais }\end{array}$ \\
\hline Folículos linfoides isolados & $\begin{array}{l}\text { Local de início das respostas imunes adaptativas, estrutura } \\
\text { organizada de populações de células imunes, não encapsulada }\end{array}$ \\
\hline Placas de Peyer & $\begin{array}{l}\text { Local de início das respostas imunes adaptativas, } \\
\text { estrutura organizada de vários folículos linfoides } \\
\text { com centros germinativos, não encapsulada }\end{array}$ \\
\hline Tecido linfoide difuso & $\begin{array}{l}\text { Macrófagos, células dendríticas, mastócitos, linfócitos T } \\
\text { efetores, células T reguladoras, plasmócitos secretores } \\
\text { de lgA dispersos na lâmina própria da mucosa }\end{array}$ \\
\hline Linfonodos mesentéricos & $\begin{array}{l}\text { Local de início das respostas imunes adaptativas contra } \\
\text { antígenos intestinais trazidos pelo sistema linfático }\end{array}$ \\
\hline
\end{tabular}




\subsection{MICROBIOTA INTESTINAL E O SISTEMA IMUNOLÓGICO}

Os seres humanos possuem trilhões de microrganismos (bactérias, vírus, fungos) associados às diversas regiões do corpo e são coletivamente chamados de microbiota ou microrganismos comensais. Todas as superfícies epiteliais do corpo humano, como a pele, cavidade oral, tratos respiratório, genital e gastrointestinal, abrigam diversos microrganismos comensais, sendo que no trato gastrointestinal estima-se que há mais de 100 trilhões de células bacterianas e cerca de 100-150 espécies de bactérias no intestino.

A colonização microbiana humana tem início na vida intrauterina a partir da microbiota materna e vai se desenvolvendo ao longo da vida do indivíduo. Após o nascimento, o aleitamento materno auxilia nesse processo uma vez que contém em sua composição oligossacarídeos (prebióticos) que estimulam a colonização.

$\mathrm{Na}$ vida adulta, os hábitos alimentares influenciam a composição da microbiota e de forma importante, a ingestão de fibras solúveis, precursores de ácidos graxos de cadeia curta, produzidos pela microbiota, podem contribuir nas respostas anti-inflamatórias através da ligação a receptores acoplados à proteína $G$ (GPRs) nas células imunes.

Assim, a microbiota intestinal exerce um papel importante no desenvolvimento e maturação das células do sistema imune do hospedeiro. Além disso, diversos estudos mostram que alterações da microbiota, denominadas disbiose, influenciam fortemente diversos processos patológicos nos seres humanos, uma vez que parecem estar relacionadas com o desenvolvimento de doenças inflamatórias intestinais, autoimunes, metabólicas (obesidade e síndrome metabólica) e até mesmo neurológicas. É importante destacar que algumas doenças são a causa primária do estabelecimento da disbiose no hospedeiro, como é o caso da síndrome da imunodeficiência adquirida (SIDA).

Diversos mecanismos imunológicos atuam no controle e na composição da microbiota intestinal, na tentativa de manter a relação de simbiose entre o hospedeiro e os microrganismos, promovendo homeostasia e prevenindo o desenvolvimento de doenças inflamatórias. Alterações no reconhecimento de PAMPs por TLRs e NLRs em células da imunidade inata e células epiteliais intestinais, bem como produção insuficiente de defensinas pelas células de Paneth e de muco pelas células caliciformes podem afetar a composição da microbiota. Células (células Th17, células T reguladoras e células B) e moléculas (IgA) da imunidade adaptativa também influenciam e são influenciadas pela composição da microbiota.

Sendo assim, o controle da composição microbiana pode ter um fim terapêutico, uma vez que esse controle é capaz de influenciar respostas imunológicas. O desenvolvimento de estratégias que modulem a composição da microbiota para um perfil terapêutico é o foco de pesquisas em todo o mundo. Entre essas 
estratégias está a administração de microrganismos isolados para o hospedeiro (probióticos), de oligossacarídeos dietéticos que aumentam a população microbiana (prebióticos), de produtos do metabolismo microbiano com ação benéfica (pósbióticos) ou até mesmo a transferência de micobiomas inteiros (transplante de soluções fecais).

\subsection{ALGUNS EXEMPLOS DE DOENCCAS CAUSADAS POR DISFUNÇÕES DAS RESPOSTAS ÍMUNOLÓGICAS NA MUCOSA INTESTINAL}

Haja vista a complexidade dos mecanismos imunólogicos envolvidos na proteção e manutenção da homeostasia intestinal, o desenvolvimento de respostas imunes direcionadas de forma inadequada contra antígenos provenientes de componentes da dieta ou da microbiota podem causar doenças intestinais.

\subsubsection{DOENÇA DE CROHN}

A doença de Crohn é um tipo de doença inflamatória intestinal, que acomete todo o trato gastrointestinal, na qual há uma resposta anormal da imunidade intestinal contra antígenos luminais em indivíduos geneticamente predispostos. Sugere-se que o primeiro passo para desenvolvimento da doença seja o aumento da permeabilidade intestinal, permitindo a passagem de antígenos derivados de bactérias comensais para a submucosa e a lâmina própria intestinal. Em pacientes com doença de Crohn, a resposta imune está desequilibrada como resultado de vários fatores, dentre eles a predisposição genética (mutações nos genes NOD2, TLR-4, CARD9, IL-23R, entre outros), mecanismos de autofagia alterados e aumento da citotoxicidade das células T. Assim, há um aumento do recrutamento celular e a produção de citocinas próinflamatórias, em associação com níveis diminuídos de citocinas imunossupressoras.

\subsubsection{DOENÇA CELÍACA}

A doença celíaca é uma doença inflamatória da mucosa intestinal, resultado de uma resposta imune exacerbada contra proteínas no glúten (encontrado em cereais como trigo, centeio, cevada, entre outros). A doença celíaca é a intolerância alimentar mais frequente na população mundial e se manifesta principalmente na infância, mas pode acometer indivíduos de qualquer faixa etária. É caracterizada por atrofia total ou subtotal da mucosa do intestino delgado proximal e consequente má absorção de alimentos, acomentendo indivíduos geneticamente suscetíveis. Diversas falhas nos mecanismos imunológicos contribuem para o desenvolvimento da doença celíaca, como: alterações na barreira epitelial intestinal, 
resposta imune humoral e celular excessiva que perpetuam o processo inflamatório e aumentam a permeabilidade intestinal, destruição dos enterócitos e atrofia das vilosidades mediados por linfócitos intraepiteliais.

\subsubsection{ALERGIAS ALIMENTARES}

Algumas proteínas (alérgenos) contidas em determinados alimentos, como nozes, amendoins, leite e frutos do mar, podem induzir uma resposta imune exacerbada dependente de linfócitos T efetores de perfil Th2 e da imunglobulina IgE, em indivíduos geneticamente predispostos. Nas gastroenteropatias alérgicas, o alérgeno alimentar ingerido interage com imunoglobulinas $\operatorname{IgE}$ na superfície de mastócitos intestinais e provoca a liberação de mediadores pré-formados (histamina, proteases) e induz a síntese de mediadores lipídicos e citocinas por essas células que causam hiperemia, aumento da permeabilidade vascular e contração do músculo liso. Além disso, em alguns pacientes, poderão ocorrer manifestações extraintestinais, como, por exemplo, rush cutâneos.

\subsection{CONCLUSÃO}

O trato gastrointestinal compreende ampla superfície de permeabilidade seletiva em nutrientes em contato constante com uma diversificada microbiota intestinal e também agentes potencialmente patogênicos. Possui o maior conjuto de linfócitos de todo o corpo humano e também maior quantidade de anticorpos produzidos. A mucosa do trato intestinal representa uma via potencial de entrada de microrganismos, e seus produtos precisam ser controlados para limitar seu acesso ao restante do corpo. Nesse sentido, o trato gastrointestinal possui conjuntos de células imunes agregadas e dispersos na mucosa que medeiam processos da resposta imunológica inata e adquirida atuantes na eliminação de agentes patogênicos e na manutenção da homeostasia intestinal, evitando respostas contra antígenos alimentares e da microbiota. Falhas nos mecanismos reguladores e o desenvolvimento de uma resposta imune exacerbada na mucosa podem causar doenças inflamatórias graves. Conhecer as bases do sistema imunológico associado à mucosa intestinal é fundamental para compreender como acontecem os processos de interação do organismo humano com o meio que o cerca. 


\section{REFERÊNCIAS BIBLIOGRÁFICAS}

ABBAS, K. A.; LICHTMAN, A. H.; PILLAI, S. Imunologia Celular e Molecular. 7 ed. Rio de Janeiro: Editora Elsevier, 2011.

BERG, R. D.; GARLINGTON, A.W. Translocation of certain indigenous bacteria from the gastrointestinal tract to the mesenteric lymph nodes and other organs in a gnotobiotic mouse model. Infect. Immun. 23: 403-411,1979.

BRANDTZAEG, P.; KIYONO, H.; PABST, R.; RUSSELL, M.W. Terminology: nomenclature of mucosa-associated lymphoid tissue. Mucosal Immunol. 1(1): 31-37, 2008.

CARIO, E.; GERKEN, G.; PODOLSKY, D. K. Toll-like receptor 2 enhances ZO-1-associated intestinal epithelial barrier integrity via protein kinase C. Gastroenterology. 127: 224-238, 2004.

CHEROUTRE, H.; LAMBOLEZ, F.; MUCIDA, D. The light and dark sides of intestinal intraepithelial lymphocytes. Nat. Rev. Immunol. 17: 445-56, 2011.

CHOUDHRY, M. A.; FAZAL, N.; GOTO, M.; GAMELLI, R. L.; SAYEED, M. M. Gut associated lymphoid $\mathrm{T}$ cell suppression enhances bacterial translocation in alcohol and burn injury. Am. J. Physiol Gastrointest. Liver Physiol. 282: G937-G947, 2002.

DIELI-CRIMI, R.; CENIT, M. C.; NÚNEZ, C. The genetics of celiac disease: A comprehensive review of clinical implications. Journal of Autoimmunity. 64: 26-41, 2015.

FARIA, A. M.; WEINER, H. L. Oral tolerance and TGF-beta-producing cells. Inflamm. Allergy. Drug. Targets. 5(3): 179-190, 2006.

FARIA, A. M.; WEINER, H. L. Oral tolerance. Immunol Rev. 206: 232-259, 2005.

FUKATA, M., HERNANDEZ, Y., CONDUAH, D., COHEN, J., CHEN, A., ET AL. Innate immune signaling by Toll-like receptor-4 (TLR4) shapes the inflammatory microenvironment in colitis-associated tumors. Inflamm. Bowel. Dis. 15: 997-1006, 2009.

GOMMERMAN, J. L.; ROJAS, O. L.; FRITZ, J. H. Re-thinking the functions of IgA+ plasma cells. Gut Microbes. 5: 652-62, 2014. 
HAYDAY, A., GIBBONS, D. Brokering the peace: the origin of intestinal T cells. Mucosal Immunol. 1: 172-174, 2008.

HOOPER, L. V., MACPHERSON, A. J. Immune adaptations that maintain homeostasis with the intestinal microbiota. Nat. Rev. Immunol. 10: 159-169, 2010.

IZCUE A.; POWRIE, F. Special regulatory T-cell review: Regulatory T cells and the intestinal tract-patrolling the frontier. Immunology. 123(1): 6-10, 2008.

JUNG, C.; HUGOT, J. P.; BARREAU, F. Patches: The Immune Sensors of the Intestine. International Journal of Inflammation. 2010.

KURASHIMA, Y.; GOTO, Y.; KIYONO, H. Mucosal innate immune cells regulate both gut homeostasis and intestinal inflammation. European Journal of Immunology. 43: 3108-3115, 2013.

MANUC, T. E.; MANUC, M. M.; DICULESCU, M. M. Recent insights into the molecular pathogenesis of Crohn's disease: a review of emerging therapeutic targets. Clin. Exp. Gastroenterol. 15: 59-70, 2016.

MASLOWSKI, K. M.; VIERA, A. T.; NG, A.; KRANICH, J.; SIERRO, F.; YU, D.; SCHILTER, H.C.; ET AL. Regulation of inflammatory responses by gut microbiota and chemoattractant receptor GPR43. Nature. 461(7268): 12821286, 2009.

MAYER, L. Mucosal Immunity. Immunol Rev. 206-205, 2005.

MUSILOVA, S.; RADA, V.; VLKOVA, E.; BUNESOVA, V. Beneficial effects of human milk oligosaccharides on gut microbiota. Beneficial Microbes. 5(3): 273-283, 2014.

OWENS, W. E., BERG, R. D. Bacterial translocation from the gastrointestinal tract of athymic (nu/nu) mice. Infect. Immun. v.27: 461-467, 1980.

PALM, N. W.; ZOETE, M. R.; FLAVELL, R. A. Immune-microbiota interactions in health and disease. Clinical Immunology. 159: 122-127, 2015.

PARSLOW, T. G.; STITES, D. P.; TERR, A. I.; IMBODEN, J. B. Imunologia Médica. 10 ed. Rio de Janeiro: Editora Guanabara Koogan, 2004. 
PEREZ-LOPEZ, A.; BEHNSEN, J.; NUCCIO, S. P.; RAFFATELLU, M. Mucosal immunity to pathogenic intestinal bacteria. Nat. Rev. Immunol. 16(3): 13548, 2016.

QUEIROZ, C. A. A.; FONSECA, S. G.; FROTA, P. B.; FIGUEIREDO, I. L.; ARAGAO, K. S. ET AL. Zinc treatment ameliorates diarrhea and intestinal inflammation in undernourished rats. BMC Gastroenterology. 14: 1, 2014.

SHANG, L.; FUKATA, M.; THIRUNARAYANAN, N.; MARTIN, A. P.; ARNABOLDI, P.; MAUSSANG, D. ET AL. Toll-like receptor signaling in small intestinal epithelium promotes B-cell recruitment and IgA production in lamina propria. Gastroenterology. 135: 529-538, 2008.

ZIBERMAN-SHAPIRA, G.; ZMORA, Z.; ITAV, S.; BASHIARDES, S.; ELINAV, H.; ELINAV, E. The gut microbiome in human immunodeficiency virus infection. BMC Med. 14(1): 83, 2016. 
